DOI: 10.17707/AgricultForest.62.4.28

\author{
Aleksandra DESPOTOVIĆ, \\ Miljan JOKSIMOVIĆ and Miomir JOVANOVIĆ ${ }^{1}$
}

\title{
SOCIO-ECONOMIC DEVELOPMENT REQUIREMENTS FOR AGROTOURISM IN MONTENEGRO
}

\begin{abstract}
SUMMARY
Rural areas are consisted of areas around city settlements inhibited by rural population, whose main activity is agriculture. Rural tourism is developing in areas where natural environment is preserved and where local community with its culture and cultural heritage exists. Agrotourism is a form of rural tourism, which includes the stay of tourists in rural areas and gives them the opportunity to actively participate in the life and work on the farm. Montenegro is abundant in areas of exceptional value that represent real environmental oases. Such regions are featured by traditional culture and diversity of the cultural heritage. On the other hand, rural areas are affected by the process of "discharge" and "dying" of villages. The process of industrialization after World War II caused depopulation and deagrarisation. These are the most significant socio-economic changes in Montenegro, which have left a negative impact on rural development.

Economic purpose of agroturism is reflected in the activation of the agricultural population, and in linking agricultural production with tourism. Its role is also important in order to decrease the population migrations from the countryside. Human factor plays an important role regarding the development of agrotourism activities. Human resources imply knowledge, experience, creativity, innovation and ability of individuals focussed on the advancement of society, and in their need to constantly invest (Đerčan, Bubalo Živković and Lukić, 2010 a). Agrotourism is an opportunity for overcoming regional differences in Montenegro and revitalization of villages in the northern part of Montenegro.

The paper analyzes the social economic conditions for development of agroturism in Montenegro. The focus is on the northern part of Montenegro on the ground of the existence of natural resources on the one hand and the lack of socio-economic conditions on the other. Development of agroturism is observed from the standpoint of improving the quality of life and improvement of agricultural production on family farms. The popularity and demand of tourists to stay in conditions of untouched nature provides an opportunity for rural areas in the north of Montenegro to adequately valorise their natural resources. In 2009, Author Ružić, points out that the rural forms of tourism valorise all those values
\end{abstract}

\footnotetext{
1 Aleksandra Despotović, Miljan Joksimović, Miomir Jovanović (corresponding author: miomirj@t-com.me), University of Montenegro, Biotechnical Faculty, Podgorica, MONTENEGRO

Notes: The authors declare that they have no conflicts of interest. Authorship Form signed online.
} 
that rural areas provide to the modern man, such as return to the natural values, agricultural environments, depressurisation from the stresses of urban areas and etc.

Key words: rural areas, agroturism, socio-economic prerequisites, regional development

\section{INTRODUCTION}

Agrotourism in Europe has begun to develop before the end of the $20^{\text {th }}$ century. Review of domestic and foreign literature reveals a number of different definitions of agrotourism. Terms agritourism, tourism on farms, tourism and related ones are often used interchangeably with agroturism and with each other (Barbieri and Mshengu, 2008; Roberts and Hall, 2001; Wall, 2000). In 2006, Marques, highlighted a specific aspect of rural tourism by which the house must be integrated into the farm, inhabited by an owner, allowing friends to participate in activities on the farm. In 2007, McGehee, and Kim Jennings defined agroturism as rural household which jointly included working farms and commercial tourist component. Theoretical and practical understanding of agroturism is very different. According to the authors Vrsaljko, Viljac 2015, rural tourism is a primary branch, rural tourism secondary, and agroturism is tertiary branch of tourism in rural areas. The main difference between these terms is in the area of implementation.

Rural tourism facilities are located throughout the rural area, rural part in part of rural area, which belongs to the village, while agri-tourist are located on farms. On the basis of available sources of literature it can be concluded that terms and farm tourism agriturism often used in Western Europe, while the term agroturism is more used in Eastern Europe (Vrsaljko, Viljac 2015). Kušen, in his considerations, suggests that the term "rural tourism" can be replaced with two others "rural tourism" and "rustic tourism" or "tourism on family farms" (Brščić, Franić et al., 2010 according Kušen, 1995). Agro tourism implies services of supply, accommodation and meals, including a country atmosphere and the economic, cultural and other areas of activity (Grgić et al., 2011). Author (Clemens 2004) observes agroturism from the standpoint of possibility of additional earnings on farms, that have a relatively small arable land, high cost of labour and difficult conditions for agricultural production. Diversification of agricultural activities in the agroturism has an impact on increasing the income of farmers, but due to need of farmers to acquire new knowledge and skills regarding agroturism, it has affects on the identity of the farmers (Siti-Hajar et al., 2015). Although the rural development policy, pay more attention to agro tourism, this activity is still insufficiently valorised through tourism offer (Vogt, 2013). Linderhof and Reinhard (2012) researched both the impact of EU rural development policy on the development of agroturism and its influence on the area using econometric analysis. Regardless of the number and diversity of the definitions on agri-tourism, the essence is focused on rural (local) economy and activities in nature. Local population gains the greatest benefit in comparison to 
the tourist agents and hotels. Rural tourism is such a form of tourism that includes the complexity of all activities and aspects of integrated tourism products (recreation in rural areas, enjoying in nature, cultural tourism, tourism on farms), (Jafari, 2000). In some countries, the term is understood differently in practice. In Finland, renting a small rural house to tourists also includes catering services. In Slovenia, the most important form of tourism is on agricultural households-farms. In the Netherlands is meant camping on family farms (Jelinčić, 2007). Common characteristics are key elements identifying the agroturisam are quiet environment, preserved nature, accommodation in traditional rural households and home-cooked food.

Rural areas, which is a basic resource for the development of rural tourism covers about $90 \%$ of the territory of Montenegro. According to the OECD methodology, Northern region encompasses 13 municipalities in its composition and it is predominantly rural (59.7\% of population lives in rural areas), while the Coastal (41.7\%) and Central (20.4\%) belongs to the transitional one. Family farms play the most important role in rural areas. According to the last agricultural census of 2010 , the total number of farms was 48870 , of which 48 824 are family farms, or $99 \%$, while only 46 companies were engaged in agricultural activity (Census of Agriculture, 2010). Introducing tourism activities in rural areas provides opportunity to family farms to improve their economic efficiency. The paper will present the existing natural and socio-economic conditions for development of agroturism on family farms, with an emphasis on the northern region of Montenegro. It will also highlight the advantages and disadvantages, as well as limitations in the development of agrotourism.

\section{MATERIAL AND METHOD}

The paper analyzes the natural and socio-economic preconditions for the development of agroturism in Montenegro. The focus of research is in the Northern region of Montenegro, namely, family farms, which are recognized as potential for the development of agroturism. In order to assess the state of the natural and socio-economic preconditions, statistical data of the last Census of Agriculture (2010) year were used. As a complement to the statistical data surveys conducted on 60 subjects in the municipalities of Pljevlja, Bijelo Polje and Kolasin were used. Also, we used the domestic and foreign literature and online sources. The questionnaire was consisted of 35 questions and it was intended for agricultural farms. The data were analyzed and statistically analyzed by descriptive statistics and using SPSS program.

For displaying the data, the statistical tables and graphs were used. Available data were analyzed by methods of description and comparison. The work is held according to the SWOT analysis in order to demonstrate the advantages and disadvantages better, as well as threats and constraints for the development of agroturism in Montenegro. It was used and the method of research desk "desk research". 
The paper aims to draw attention to the fact that agroturism is important for overcoming regional disparities, as well as to increase the income of the farms and the increasing employment of women.

\section{RESULTS AND DISCUSSION}

Last sixty years have witnessed major changes in the way of life in rural areas of Montenegro. Such changes resulted in an uneven development of the regions. According to the Regional Development Strategy of Montenegro, three regions are classified: Northern, Central and Southern region. Depopulation of the Northern region is greatly expressed, as well as the high concentration of population and economy in the central and southern region. Rural area of Montenegro remains discharged, while on the other side - in Europe rural areas are becoming increasingly important alternative of living and working in relation to cities. Tourists are constantly looking for new and different forms of tourism. Agrotourism covers individual regions and it is becoming a regional macroeconomic challenge. It is not only economic but also sociological, geo-strategic and political category (Pejanović 2008). Agrotourism gains its importance primarily due to the needs of the modern consumer to stay in the rural environment and live in a harmony with nature. Author (Pejanović 2008) points out that the experience of rural and regional development in the EU shows that the development of agrotourism enables: stabilization of the regional development, resource utilization, preservation of tradition, optimization of the rural and urban regions and raising the competitiveness of certain regions as tourist destinations. Through the indirect economic impacts on agriculture indirectly, tourism stimulates development of other activities. Economic effects of rural areas can be numerous: development of abandoned rural communities through the process of valorisation of rural houses, abandoned farms, through return of young people to the countryside, revival of traditional crafts, etc.

Average farm in Montenegro has 4.6 ha of agriculturally used land (Statistical Office of Montenegro - MONSTAT 2011). Taking into account the size of households, development of agrotourism provides an opportunity for diversification of their activities and achieving favourable economic results. It could be a significant supplementary activity on the farm, which ensures better usage of production capacity and labour of household members. The main characteristic of family farms is high proportion of older working-age population on the farm and a small number of young people. Aged households cannot be a basis for the development of tourism in the country. According to (Franjic and Grgić, 2002), the owners of farms who would like to operate in field of agroturism should assess whether their household is suitable for providing tourism services and evaluate properties of their household members, age and willingness of the family to kindly treat the guests. Development of agrotourism is an opportunity to stop emigration of young people from rural areas and it generally affects on decrease in migration flows. On family farms in Montenegro 6717 persons were under 24 years old, which makes $6.83 \%$ of the total workforce 
(Figure 1). On family farms 23198 working-age population is aged 65 and over, which makes $23.58 \%$ of the total workforce.

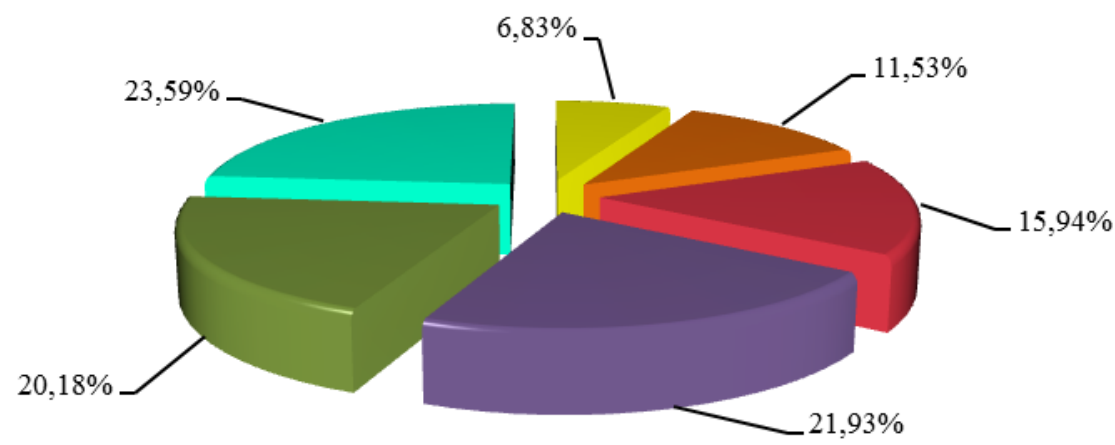

Up to 24 years

Between 24 and 35 years $=$ Between 35 and 44 years

Between 45 and 54 years Between 55 and 64 years $\$ 65$ years and over

Source: Agricultural Census 2010, Structure of agricultural holdings by municipalities

Graph. 1. Labour force family agriculture holdings

Employability of women in agriculture accounts for only $4 \%$ of total employment. The main reasons for lack of interest of women to remain in rural communities are the following: women in rural areas rarely own property, are rarely found in the position of holders of holdings and rarely have the role of decision-making on agricultural production and the role of responsibility for the economic risks of operations on the farm. According to the Census of Agriculture, women comprise only $12.87 \%$ of holders of family farms. Approximately $33.24 \%$ of holders of holdings are aged over 65 or more and they are mostly men. Unfavourable educational structure creates a low potential for successful economic participation of women and significantly reduces their employability. In fact, development of agroturism can positively affect not only the development of women entrepreneurship, but also entire agroturism offer. Rural tourism in Greece is used as important means of social promotion of female population (Grgić et al. 2015).

The best example of the use of agroturism as "tools" in the development of rural areas represents Austria. In fact, Austria is in the area of the Alps and it began with the revitalization and development of non-agricultural activities in $50 \mathrm{~s}$ of the $20^{\text {th }}$ century. Today Austria is the leading European country in agrotourism with a long tradition and great experience, especially in maintaining farms in mountain regions. Italy is the only country in the European Union which has a special law on agrotourism, while the rest of the countries of this form of tourism include in the general provisions. In neighbouring Croatia, the first registered farms have emerged in 1998. In the period 2000-2005, the number of 
registered farms has doubled. In 2013, there were 447 farms, which are engaged in agrotourism, but they are very unevenly distributed in the counties. The biggest advancements are made in the field of agrotourism in Istria (Grgic et al. 2015).

From the standpoint of education of the labour force on family farms in Montenegro, and according to available data, the highest share belongs to people with 4 years of high school (33.74\%), of which $66.88 \%$ are men and $33.22 \%$ are women. The share of people with secondary or higher agricultural education is at the level of $1.47 \%$ of the total workforce of family farms. Men with secondary or higher agricultural education accounted for about $72.89 \%$ and $25.63 \%$ women. Human resources play an important role in the development of agrotourism. All those who work on farms and who are involved in agrotourism, apart from knowledge needed to carry out agricultural activities, must possess a certain entrepreneurial and communication skills, and also culture of communicating with people (Grgić et al. 2015). If we look at the number of members on the farm, most of those farms have 1 to 2 members, and they accounted to $76.8 \%$. Analysis of the situation on family farms indicates that apart natural conditions, human resources are of a great importance for the development of agroturism. A special advantage of agrotourism, in relation to other forms of tourism is its perennial character, or functionality of 365 days (Pejanović 2008).

The development of agrotourism can significantly influence and lead to a reduction in regional differences in Montenegro that are highly expressed. The graph 2 shows the movement of the population by region in the period 1948-2011.

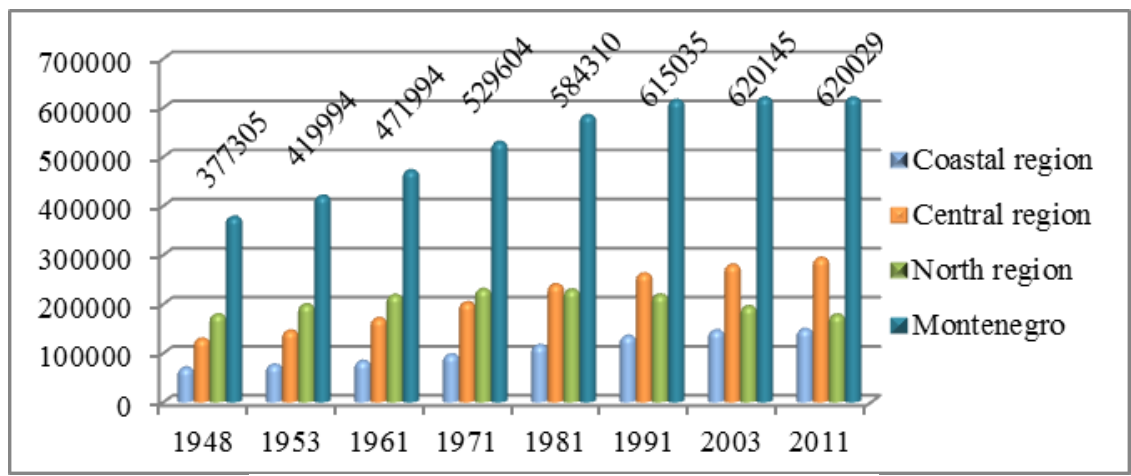

Source: Statistical Office of Montenegro - MONSTAT, 2008

Graph 2. Movements in the total population of Montenegro by regions, 1948-2011

Since the Census of 1981, share of the population of the Southern and Central regions of the total population of Montenegro has been increasing, while share of population of the Northern region is declining. Population of the Coastal region has increased by $29.73 \%$, the Central by $38.30 \%$, while the North was reduced by $39.92 \%$ (Despotović, et al., 2015). This trend has resulted in the weaker pace of development of agriculture. Northern region (mainly rural) 
represents more than $50 \%$ of the country, but is inhibited by less than a third of total population. On the other hand, nearly one-quarter of the population in Montenegro inhabit slightly over $10 \%$ of the territory of Montenegro. EU experiences indicate that the development of agrotourism ensures stabilization of the regional development and increase of the competitiveness of the region as a tourist destination.

In Montenegro, the agrotourism is still seeking its place in regional development and development in general. The essence of offer in rural areas is a stay in the renovated village houses with the possibility of preparing food, familiarizing with traditions and revival of many traditional activities. Tourism would encourage the development of other activities in rural areas, which would be directly or indirectly involved in providing services to tourists, such as: transport, trade, production of food, drinks and other activities. However, there are little concrete activities that were directed towards the development of agrotourism. The reasons should be sought in the fact the potential for developing this type of tourism has not still been recognized, but also in a lack of knowledge of those subjects that should work on the promotion of agrotourism. Therefore, we can conclude that the agrotourism in Montenegro is still in its infancy and it is necessary to be worked on its affirmation. In order to learn what farmers think and know about agrotourism, a survey on 60 family households in the Northern area of Montenegro, or more precisely in Kolašin, Pljevlja and Bijelo Polje was conducted. The survey implied 35 questions, which included socio-economic characteristics of households and their production status.

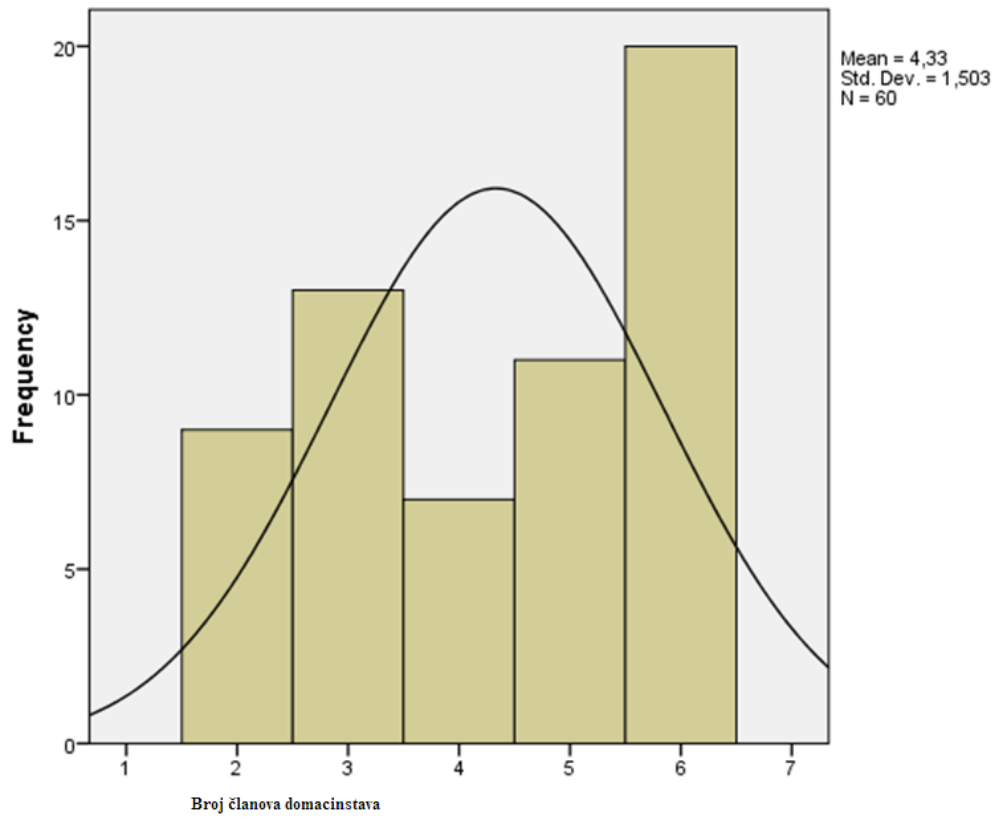

Source: Survey, 2016

Graph 3 Number of household members 
The survey covers respondents aged over 18. The sample included randomly selected households, which are located in areas suitable for the development of agrotourism. Agricultural producers accounted for $62.3 \%$ of respondents, while the rest were pensioners, housewives and workers. Regarding the gender structure of the survey - $90 \%$ of men and $10 \%$ women were included. The paper will present the results of a number of key issues important for the development of agrotourism. More than $50 \%$ of respondents are personal owner of the farm, i.e. of the available land, while statistically significant number of respondents stated that about $34 \%$ of land in the ownership possession belongs to the parents of the respondents. Over $30 \%$ of respondents said that they live in a community with more than 5 household members (Graph 3), which is significantly higher than the average in Montenegro.

Table 1. Comparison of strengths, weaknesses, opportunities and constraints in the development of agroturism in Montenegro

\begin{tabular}{|c|c|}
\hline Advantages (Strengths) & Disadvantages (Weaknesses) \\
\hline $\begin{array}{l}\text { Preserved natural heritage } \\
\text { Favourable geographical position } \\
\text { Favourable natural conditions } \\
\text { Diversity of agricultural production } \\
\text { Hospitality of local population } \\
\text { Traditional and authentic products } \\
\text { Rich gastronomic offer } \\
\text { Rich historical and cultural heritage } \\
\text { Conditions for organic production }\end{array}$ & $\begin{array}{l}\text { Depopulation, or migration of young } \\
\text { people to the cities } \\
\text { Mostly elderly population in rural areas } \\
\text { Low quality of life in rural areas } \\
\text { Underdeveloped infrastructure } \\
\text { Lack of heritage } \\
\text { Low level of knowledge in the field of } \\
\text { agrotourism } \\
\text { Lack of funding } \\
\text { Unclear legislation } \\
\text { Inadequate incentives for development }\end{array}$ \\
\hline Possi & \\
\hline $\begin{array}{l}\text { Increase in demand for rural households } \\
\text { Increased demand for organic products } \\
\text { New tourism trends } \\
\text { Raising awareness of local people about } \\
\text { the importance of agrotourism } \\
\text { Preservation of the environment } \\
\text { Stimulation for entrepreneurship } \\
\text { Valorisation of cultural heritage } \\
\text { Placement of own agricultural products } \\
\text { Incentives by the EU }\end{array}$ & $\begin{array}{l}\text { Migration of youth and women } \\
\text { Aging population } \\
\text { Low interest in the development of } \\
\text { agrotourism } \\
\text { Low incentive for balanced regional } \\
\text { development } \\
\text { Lack of cooperation between tourist } \\
\text { agencies and agricultural producers } \\
\text { Increased pollution } \\
\text { Lack of cooperation between local } \\
\text { authorities and manufacturers } \\
\text { Insufficiently defined strategy of } \\
\text { development of agrotourism. } \\
\text { Unstable tourism market }\end{array}$ \\
\hline
\end{tabular}

Source: Synthesis of the authors based on several sources (Grgić,2015, Vrsaljko et al.,2015) 
However, the average number of household members was 4 members, while the most frequent number of repetitions went to the side of those with more than 5 members.

That the concept of working in field of agro industry is a relatively new phenomenon in Montenegro shows the fact that $85 \%$ of surveyed households are not familiar with the regulations to be observed when initiating/running agrotourism. Only $15 \%$ of households are familiar with the regulations. Although knowledge of the regulations is not a strong side of households, yet $76.7 \%$ of them showed willingness to be participating in agrotourism in the next five years. The motive for agrotourism activities in the majority of interviewee is easier placement or sale of their own products (39.3\%), as well as increasing of income, reducing the risk of agricultural production, employment of family members $26 \%$. Other interviewees were not precise in their responses. About $50 \%$ of households stated that funds are major constraint in dealing with agrotourism, but also they see demanding administrative procedures as an obstacle. $88.10 \%$ of them considered that the development of agrotourism can significantly boost socio-economic development of rural areas. The results obtained in the survey correspond to the literary sources, indicating the importance of agrotourism in terms of socio-economic development of certain regions. In order to promote its development, it is necessary to educate producers and simplify administrative procedures. Also, SWOT analysis indicates advantages, disadvantages, opportunities and constraints in the development of agrotourism in Montenegro.

\section{CONCLUSION}

Rural tourism in Montenegro is underdeveloped, and it is the result of years of neglect of rural areas. Family farms on the one hand are the backbone of the development of agroturism, and on the other hand represent a limiting factor. The structure of the land, precisely, fragmentation of holdings and insufficient number of trained persons on the farm, unfavourable age structure of the staff are just some of the factors that influence the development of agritourism. All of these limiting factors should be viewed realistically when designing agroturism offer. Results of surveys suggest that manufacturers are willing to work in agroturism if financing and permanent education is secured.

All of the above should be observed realistically keeping in mind that it is necessary to take into account the guidelines of sustainable development, supported by performance of special forms of tourism.

With the development of agrotourism, agricultural production is not only food production but it receives multifunctional role of agriculture. Eco-social model of agricultural development can create a platform for the development of policies that will improve agriculture and support the development of agroturism as an additional activity.

Experiences from other countries such as Austria, Italy, Greece, Croatia and other countries can help Montenegro when designing further development of agritourism. 


\section{REFERENCES}

Barbieri, C., and Mshengu, P.M. (2008): The role of the firm and owner characteristics on the performance of agrotorism farms. Ruralis Sociology, 48, 166-183

Brščić, K., Franić, R., Ružić, D. (2010): Why Agroturism -owner, with opinion, Journal of Central European Agriculture, Vol 11 N0 1, p 31-42

Census of Agriculture 2010, Farm Structure, Podgorica, Statistical Office of Montenegro, 2011

Clemans, R. (2004): Keeping Farmers on the Land: Agriturism and the European Union, available at http://www.card.iastate.edu/iowa_ag_review/summer_04/article4.aspxž

County: Constraints and Opportunities, Agronomy journal, (1-2): 41-58

Čurić, K. (2010): Agroturism as additional activities on family farms.

Đerčan, B., Bubalo Živković, M. and Lukić, T. (2010a): Demographic changes in the border towns of Srem in the case of Vašice, Proceedings of the Faculty of Geography, 43, p.227-232

Despotović A., Joksimović M., Jovanović M .: (2015): Demographic trends in Montenegro and their impact on the development of agriculture, Agricultural Economics, Faculty of Hotel Management and Tourism, Vrnjci Spa, Serbia

Franić, R., Grgić, Z. (2002): Agrotourism on a Family Farm in Croatia - Prospects for Development, Agriculturae Conspectus scientifikus, Vol 67 No3, p.131-141

Grgić, I., Zrakić, M., Cerjak, M. (2011): Agro touristic offer of Zagreb

Grgić, I., Zrakić, M., Velaga-Gudelj, A. (2015): Agrotourism in the

Jafari, J. (2000): Encyclopedia of Tourism, London, Routledge

Jelincic, D.A. (2007): Agroturism in the European context, Stud.ethnol. Croatia, Vol.19, p.269-291

Linderhof, V., Reinhard, S. (2012): To the rural development program measures for the encouragement of rural tourism work. A spatial econometric analysis Europen 52nd Congress of the Regional

Marques, H. (2006): Searching for Complementarities betwen agriculture and tourism -the dermacated -Producing wine regions of northern Portugal. Tourism Economics, 12, 147-155

McGehee, NG, Kim, Kis. And Jennings, G. R. (2007): Gender and motivation for agi -toursm entrepreneurship. Tourism Management, 28.280-289

Pejanović, R., Vujović, S. (2008): Rural development and agroturism, Agricultural Economics, Faculty of Agriculture, Novi Sad, Vol.37-38, p.5-14

Practical Management, Vol. I, No. 1, p. 101-105

Republic of Croatia and some countries of the European Union, Agronomy journal, 1-2 / 2015, str.61- 74

Ružić, P. (2009): Rural tourism, Porčc, Institute for Agriculture and Tourism, Poreč

Siti Hajar-Z, Fadzilah, M.S., Muzzamir, M., Norsalin, A. H. (2015): Entrepreneurial knowledge and hospitality awereness of agro-Torism in Theory and pracitce on hospitality and Touris Research

Statistical Office of Montenegro - MONSTAT (2008): Demographic trends in Montenegro since the mid-twentieth century and prospects to 2050

Statistical Office of Montenegro - MONSTAT (2011): Agricultural census 2010 structure of agricultural holdings, Used land, Podgorica, Montenegro

Vogt, L. (2013): The economic side of Agroturisme: business performance and competitive factors, Economia Agro-Alimentare, No.3, 77-102

Vrsaljko, A., Viljac, M. (2015): Agriturizam in Split-Dalmatia County in comparison with Bavaria, Agronomy journal, 4-6 / 2015, p.185-206 